\title{
FDA Action Letter
}

National Cancer Institute

\section{Source}

National Cancer Institute. FDA Action Letter. NCI Thesaurus. Code C142550.

A letter from the Food and Drug Administration to a study sponsor announcing an agency decision about approval or non-approval. Action letters include Untitled and Warning Letters. 